\title{
Multi-input DC-AC Inverter for Hybrid Renewable Energy Power System
}

\author{
Mohd Azman Rosli, Nor Zaihar Yahaya, Zuhairi Baharudin \\ Department of Electrical and Electronic Engineering, Petronas University of Technology, Malaysia
}

\begin{tabular}{l}
\hline \hline Article Info \\
\hline Article history: \\
Received Aug 18, 2015 \\
Revised Dec 2 25, 2015 \\
Accepted Dec 15, 2015 \\
\hline
\end{tabular}

\section{Keyword:}

Fuel cell

Hybrid power system

Multi-input inverter

Photovoltaic array

PWM controller

Wind turbine

\begin{abstract}
The objective of this paper is to design a multi-input dc-ac inverter integrated photovoltaic array, wind turbine and fuel cell in order to simplify the hybrid power system and reduce the cost. The output power characteristics of the photovoltaic array, wind turbine and fuel cell are introduced. The operational principle and technical details of the proposed multi-inputdc-ac inverter is then explained. The proposed inverter consists of a three inputflyback dc-dc converter and a single phase full bridge dc-ac inverter. The control strategy for the proposed inverter to distribute the power reasonably to the sources and it achieved a priority of the new energy utilization is discussed. This multi-input dc-ac inverter is capable of being operated in five conditions and power delivered to the acload can be either individually or simultaneously. First to third condition occurs when the power delivered from either renewable energy sources individually, fourth condition happens when power is demanded from two sources simultaneously, and finally when power are available from three sources simultaneously. The proposed inverter has been simulated by employing NI Multisim 12.0 circuit simulator.
\end{abstract}

Copyright (C) 2016 Institute of Advanced Engineering and Science. All rights reserved.

\section{Corresponding Author:}

Nor Zaihar Yahaya,

Department of Electrical and Electronic Engineering,

Universiti Teknologi Petronas,

Bandar Seri Iskandar, Tronoh 31750, Perak, Malaysia.

Email: norzaihar_yahaya@petronas.com.my

\section{INTRODUCTION}

The development of alternative energy sources is continuously increasing because of the limited conventional energy sources such as oil, gas and others. Nowadays, the conventional energy sources are currently decreased and future will collapse. Moreover, environmental concerns such as global warming are becoming increasingly serious and require significant attention and planning to solve. Renewable energy (RE) sources are the answer to these needs and concerns, since they are available as long as the sun is burning and because they are sustainable as they have no or small impact on the environment. With the development of RE technologies, the cost of the photovoltaic (PV) arrays, wind turbines (WT) and fuel-cells (FC) are expected to decrease in future and they are gaining prominence as they are more energy efficient, reduce pollution and serve as a promising solution to the toughest energy crisis faced during the recent years.

In Malaysia, RE sources such as solar and wind energy conversion are serious consideration because the potential for both of this energy generation depends on the availability of the solar and wind resources that varies with location. Energy efficiency and renewable energy under the Eight Malaysia Plan (20012005) and Ninth Malaysian Plan (2006-2010) are focused on targeting for renewable energy to be significant contributor and for better utilization of energy resources. An emphasis to further reduce the dependency on petroleum provides for more effort to integrate alternative source of energy [1].

A hybrid renewable energy generation system (HREGS) combines more than one energy source. The main advantage of implementing HREGS is the enhancement of reliability of the system used and also 
can reduce the battery size. Nowadays, these systems are important and better than conventional systems. In order to accommodate different renewable energy sources, the concept of multi-input inverter have been proposed. Some literatureshas paid attention to HREGS recently. Most of the multi-input converters are based onmulti-input DC-DC boost converter [2], [3], [4], [5] and most of the multi-input inverters consists of a buck/buck-boost fused multi-input DC-DC converter and a full-bridge DC-AC inverter [6], [7]. The main disadvantages of these topologies are complexity in operationat wide variable input voltage from different energy sources to produce a constant output voltage to the load. Thisinverter is used in several stages in power conversion which increases the number of power switches and components and complicated control system. These disadvantages increase the cost, size and weight of the hybrid system and the control become difficult.

The objective of this paper is to propose a multi-input DC-AC inverter for hybrid PV, WT and FC power system which consists of a multi-input DC-DC flyback converter and a single phase full-bridge DCAC inverter in order to produce a constant output voltage from the different energy sources. As the power from PV and wind sources is intermittent, a charge controller is used to provide uninterrupted supply to the converter while the power from FC source is same voltage levels and constant. The advantages of the proposed multi-input DC-AC inverter are: i) simple configuration, ii) high extendibility and flexibility, iii) increase the efficiency and reliability of the inverter in a lower cost and less size, andiv) suited for hybrid renewable energy application with more than two input sources.

\section{PROPOSED HYBRID SYSTEM}

The use of separate single input inverters in HREGS leads to relatively complex configuration, high cost and low integration. As an alternative, multi-input inverter is used to reduce complexity; improve power density and reduce the cost of hybrid power systems [8]. Figure 1 shows the block diagram of proposed multi-input dc-ac inverter in HREGS. It consists of a three input flyback dc-dc converter and a single phase full bridge dc-ac inverter. The Maximum Power Point Tracking (MPPT) is dedicated to extract the maximum power point from photovoltaic array and wind turbine by using perturbation and observation of MPPT. The optimum fuel cell operation range is set by Proton Exchange Membrane Fuel Cell (PEMFC) and charging or discharging of battery is operated by the charge controller.

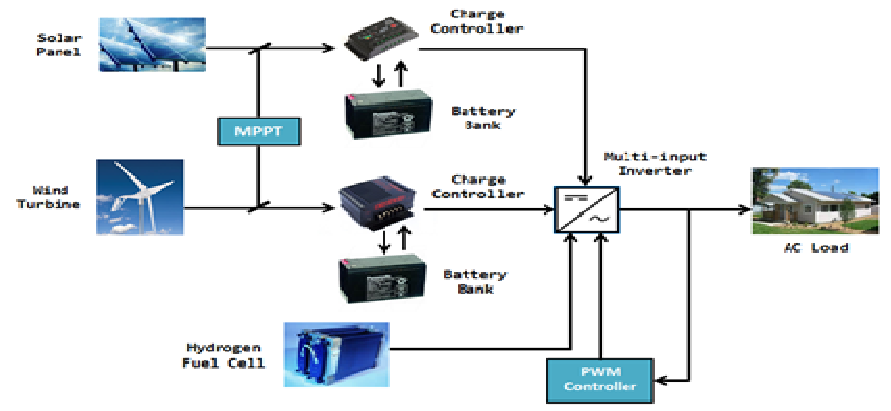

Figure 1. Block diagram of proposed multi-input dc-ac inverter application for HREGS

The power outputfrom renewable energy sources will be regulated by the three input flyback dc-dc converterutilizing Pulse Width Modulation (PWM) control scheme to the power switches. Then, the dc power output from theconverter will be stabilized by the single phase full bridge dc-acinverter using Sinusoidal Pulse Width Modulation (SPWM) control to achieve the input output power flow balance. The expected output from the inverter is $240 \mathrm{~V} \mathrm{AC}, 50 \mathrm{~Hz}$ frequency and $250 \mathrm{~W}$ power output.

\section{RENEWABLE ENERGY SOURCES}

\subsection{Photovoltaic Array}

The photovoltaic array is constructed by many series or parallel connected solar cells [9], [10]. The electromagnetic radiation of solar energy can be directly converted to electricity through photovoltaic effect.The equivalent circuit of the general model which consists of a photo current, a diode, a parallel 
resistor expressing a leakage current, and a series resistor describing an internal resistance to the current flow is illustrated in Figure 2.

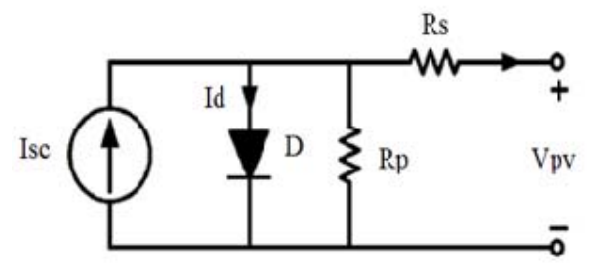

Figure 2. The equivalent circuit of a solar cell

The most common model used to predict energy production in photovoltaic cell modeling is the single diode circuit model [11]. This equivalent circuit models the general form the equation that relates current and voltage in a photovoltaic cell as given in Eq. (1) to Eq. (3).

$$
\begin{aligned}
& \mathrm{Ipv}=\mathrm{Isc}-\mathrm{Io}\left(\mathrm{e}^{\frac{\mathrm{q}(\mathrm{V}+\mathrm{IRs})}{\mathrm{kTc}}}-1\right)-\frac{\mathrm{V}+\mathrm{IRs}}{\mathrm{Rp}} \\
& \mathrm{Vpv}_{\text {cell }}=\mathrm{Vd}-\mathrm{Rs} . \mathrm{Ipv} \\
& \mathrm{Vpv}=\mathrm{Ns.} \mathrm{Vpv}_{\text {cell }}
\end{aligned}
$$

where,Ipv is solar cell current (A), Isc is light generated current (A), Io is diode saturation current (A), q is electron charge $\left(1.6 \times 10^{-19} \mathrm{C}\right), \mathrm{k}$ is Boltzmann`s constant $\left(1.38 \times 10^{-23} \mathrm{j} / \mathrm{K}\right), \mathrm{Tc}_{\mathrm{c}}$ is cell temperature in Kelvin $(\mathrm{K}), \mathrm{V}_{\mathrm{pv}}$ is solar cell output voltage $(\mathrm{V})$, Rs is solar cell series resistance $(\Omega)$, $\mathrm{Rp}$ is solar cell shunt resistance $(\Omega)$ and $N_{s}$ is number of cells in series.

A number of approaches for cells and modules parameter determination can be adopted using the datasheet of parameters specified by manufacturer or measured. The performance of solar cell is normally evaluated under the standard test condition (STC), where an average solar spectrum at AM 1.5 is used, the irradiance is normalized to $1000 \mathrm{~W} / \mathrm{m} 2$, and the cell temperature is defined as $25^{\circ} \mathrm{C}$.

\subsection{Maximum Power Point Tracking Algorithm}

In order to utilize the maximum output power from the photovoltaic array and wind turbine, an appropriate control algorithm is adopted. Generally, the maximum power point tracking efficiencies $(\eta$ MPPT) of the three common algorithms for photovoltaic array are shown in [12]. Perturbation and observation method is one of the most commonly used [13]. The perturbation of the output power is achieved by periodically changing (either increasing or decreasing) the controlled output power. The perturbation and observation method is applied to determine the changing direction of the load because the output power of the photovoltaic array and wind turbine are not constant.

\subsection{Wind Turbine}

Wind turbines convert the kinetic energy present in the wind into mechanical energy by means of producing torque. Among various types of wind turbines, the permanent magnet synchronous wind turbine, which has higher reliability and efficiency, is preferred [14], [15]. The available power of wind energy system is given in Eq. (4).

$$
\mathrm{P}_{\text {wind }}=\frac{1}{2} \rho A \mathrm{~V}^{3} \text { wind }
$$

Where, $\rho(\mathrm{kg} / \mathrm{m})$ is the air density and Ais the area swept out by turbine blade in $(\mathrm{m})$, while Vwind is the wind speed in $(\mathrm{m} / \mathrm{s})$. To describe a wind turbine power characteristic, this Eq. (4) describes the mechanical power generated by the wind. The equation is governed by Eq. (5). 


$$
\mathrm{P}_{\mathrm{m}}=\frac{1}{2} \rho A V^{3}{ }_{\text {wind }} \operatorname{Cp}(\lambda, \beta)
$$

Where, pis the air density $\left(\mathrm{kg} / \mathrm{m}^{3}\right), A$ is the area of the turbineblades $\left(\mathrm{m}^{2}\right), \mathrm{V}$ is the wind velocity $(\mathrm{m} / \mathrm{s})$, and $\mathrm{Cp}$ is the powercoefficient.The power coefficient $\left(\mathrm{C}_{\mathrm{p}}\right)$ is a nonlinear function that represents the efficiency of the wind turbine to convert wind energy into mechanical energy. It depends on two variables, the tip speed ratio (TSR) and the pitch angle. The TSR $(\lambda)$ refers to a ratio of the turbine angular speed over the wind speed. The pitch angle $(\beta)$ refers to the angle in which the turbine blades are aligned with respect to its longitudinal axis. The value of TSR is obtained from Eq. (6).

$$
\operatorname{TSR}(\lambda)=\frac{\mathrm{R} \omega}{\mathrm{V}}
$$

Where, $R$ is the radius of the rotor of the wind turbine $(\mathrm{m})$, and $\omega$ is therotational shaft speed of the wind turbine $(\mathrm{rad} / \mathrm{s})$.

\subsection{Fuel Cell}

Fuel cells are electrochemical devices that process $\mathrm{H}_{2}$ and oxygen to generate electric power, having water vapor as their only by-product [16]. There are several kinds of fuel cell. In particular, proton exchange membrane fuel cell has reached a high development status. In the last decade, a great number of researcher's has been conducted to improve the performance of the proton exchange membrane fuel cell, so that it can reach a significant market penetration.

Proton exchange membrane fuel cell primarily consists of three components: a negatively charged electrode (cathode), a positively charged electrode (anode) and a solid polymer electrolyte membrane. Hydrated hydrogen gas is supplied at the anode and air is supplied at the cathode. At the anode, hydrogen gas in the presence of the platinum catalyst is ionized into positively charged hydrogen ions and negatively charged electrons. The reaction at the anode isgiven by Eq. (7):

$$
\mathrm{H}_{2}=2 \mathrm{H}^{+}+2 \mathrm{e}^{-}
$$

There are three voltage losses involved in fuel cell output voltage when the current flowing through the external circuit. Those are activation polarization, ohmic polarization and concentration polarization. The output voltage of a single cell can be defined by the following Eq. (8):

$$
\mathrm{V}_{\mathrm{FC}}=\mathrm{E}_{\mathrm{Nernst}}-\mathrm{V}_{\mathrm{act}}-\mathrm{V}_{\mathrm{ohmic}}-\mathrm{V}_{\text {conc }}
$$

Where, VFC is the output voltage of a single cell, Enernst is the electrochemical thermodynamic potential of the cell and it represents its reversible voltage, which is an ideal output voltage. Vact is the voltage drop due to the activation of the anode and cathode. Vohmic is a measure of ohmic voltage drop associated with the conduction of the protons through the solid electrolyte and electrons through the internal electronic resistances and $\mathrm{V}$ conc represents the voltage drop resulting from the concentration or mass transportation of the reacting gases.

\subsection{Specification of Renewable Energy Sources}

The specification of the renewable energy sources such as photovoltaic array, wind turbine and fuel cell as listed in Table I are used and implemented in the proposed scheme. The table shows characteristics of solar panel model SM100, wind turbine model 100S and fuel cell model H-100PEM. 
Table 1. Specification of Renewable Energy Sources Solar Panel Model SM100

\begin{tabular}{|c|c|}
\hline Peak power output & $100 \mathrm{~W}$ \\
\hline Maximum power voltage & $17.5 \mathrm{~V}$ \\
\hline Maximum power current & $5.72 \mathrm{~A}$ \\
\hline Short circuit current & $6.30 \mathrm{~A}$ \\
\hline Open circuit voltage & $21.5 \mathrm{~V}$ \\
\hline No. and type of cell & $36 \& 72$ Mono cells \\
\hline Working temperature & $-40^{\circ} \mathrm{C} \sim 90^{\circ} \mathrm{C}$ \\
\hline \multicolumn{2}{|c|}{ Wind Turbine Model 100S } \\
\hline \multicolumn{2}{|c|}{$\begin{array}{l}\text { Wind Turbine Model 100S } \\
100 \mathrm{~W}\end{array}$} \\
\hline Maximum power & $130 \mathrm{~W}$ \\
\hline Nominal voltage & $12 / 24 \mathrm{~V}$ \\
\hline Start-up wind speed & $2.0 \mathrm{~m} / \mathrm{s}$ \\
\hline Rated wind speed & $10 \mathrm{~m} / \mathrm{s}$ \\
\hline Survival wind speed & $55 \mathrm{~m} / \mathrm{s}$ \\
\hline Generator & Permanent Magnet Synchronous \\
\hline \multicolumn{2}{|c|}{ Working temperature $\quad-40^{\circ} \mathrm{C} \sim 80^{\circ} \mathrm{C}$} \\
\hline \multicolumn{2}{|c|}{ Fuel Cell Model H-100PEM } \\
\hline Type of fuel cell & Proton Exchange Membrane \\
\hline Number of cells & 20 \\
\hline Rated power & $100 \mathrm{~W}$ \\
\hline Performance & 12V@8.3A \\
\hline Reactants & Hydrogen and Air \\
\hline \multicolumn{2}{|c|}{ Max stack temperature $\quad 65^{\circ} \mathrm{C}$} \\
\hline \multicolumn{2}{|c|}{$\mathrm{H} 2$ pressure $\quad 0.45-0.55 \mathrm{bar}$} \\
\hline Efficiency of stack & 40\%@12V \\
\hline
\end{tabular}

\section{MULTI-INPUT DC-AC INVERTER CIRCUIT TOPOLOGY}

The schematic diagram of the proposed multi-input DC-AC inverter is shown in Figure 3. It consists of a combined three input flyback DC-DCconverter topology and a single phase full bridge dc-ac inverter. By applying the PWM control scheme and driver circuit to the DC-DC converter, the power can be delivered from the source individually and simultaneously. Meanwhile, the converter output voltage will be regulated by the dc-ac inverter with the SPWM control scheme to get the constantinput-output power balance.

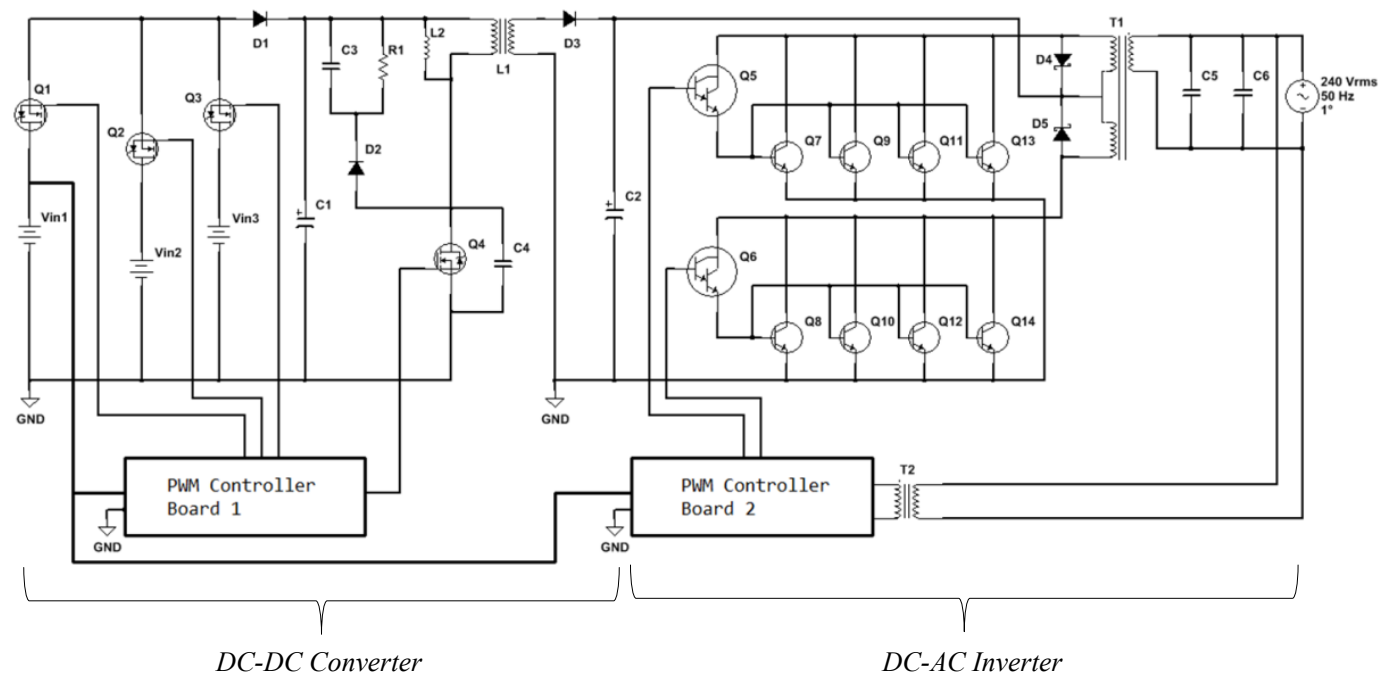

Figure 3. Schematic diagram of proposed multi-inputinverter

\subsection{Three Input Flyback DC-DC Converter}

Multiple-input DC-DC converters are used to combine several input power sources where voltage levels and/or power capacity are different for regulated output voltage [17]. The proposed isolated three input flyback DC-DCconverter has a simple isolated topology and thus incurring the lowest cost, least number of power components, easily understood and easy to implement, it is well suited for hybrid renewable energy application with more than two input sources. A flyback is a coupled inductor and is not a true based transformer converter. Theproposed converter can accept up to three input sources by other competitors with 
the same voltage level. It only has one primary coupled inductor winding, which can transfer the power to the load individually or simultaneously with lower voltage stresses on the power switches. The converter uses the principle of magnetic coupling to combine more input sources which are connected in parallel. The advantages of proposed converter are the galvanic isolation is a desired feature so that faults on one side do not affect the other side of the converter [18], and the leakage inductor energy of the coupled inductor can be recycled, thus increasing the efficiency and restraining the voltage stress across the active switch [19].

Table 2. 8-Modes operation of three input flyback DC-DC converter

\begin{tabular}{ccccccccc}
\hline Mode & Source & Q1 & Q2 & Q3 & Q4 & D1 & D2 & D3 \\
\hline 1 & Vin1 & On & Off & Off & On & On & On & Off \\
2 & Vin2 & Off & On & Off & On & On & On & Off \\
3 & Vin3 & Off & Off & On & On & On & On & Off \\
4 & Vin1+Vin2 & On & On & Off & On & On & On & Off \\
5 & Vin2+Vin3 & Off & On & On & On & On & On & Off \\
6 & Vin1+Vin3 & On & Off & On & On & On & On & Off \\
7 & Vin1+Vin2+Vin3 & On & On & On & On & On & On & Off \\
8 & Vin1+Vin2+Vin3 & Off & Off & Off & Off & Off & Off & On \\
\hline
\end{tabular}

To achieve asuccessful design of theproposed converter, the Metal Oxide Semiconductor Field Effect (MOSFET) had been choosen. In this paper, the converter adopts three input sources such as photovoltaic array, wind turbine and fuel cell. Output from this converter is connected to full bridge DCACinverter before delivering the power to the ac loads. In this section, the analysis of three input flyback DC-DCconverter topology is explained. Table 2 shows the HREGS under different operation modes by PWM controller of three input flyback converter. This table shows the equivalent circuits condition for mode 1 until mode 8 , respectively. These operating modes are employed to feed the load by optimizing the energy obtained from the renewable energy sources.

From the Table 2, Mode 1 shows the switches Q1 and Q4 are conducting while Q2 and Q3 are turned off. D1 and D2 are conducting, D3 are blocked. The photovoltaic voltage source $\mathrm{V}_{\text {in } 1}$ is applied to the primary winding of the couple inductor and current of the primary winding increases linearly. The inductor of the couple inductor accumulates energy, and the load current is provided by the filter capacitor, C2. During this mode, Q2 and Q3sustain the voltages of $V_{\text {in2 }}$ and $V_{\text {in3while }}$ D3 sustain the secondary winding voltage of couple inductor, Vsec respectively. In mode 2, Q2 and Q4 are conducting and Q1 and Q3 are off. D1 and D2 are on while $\mathrm{D} 3$ are blocked. The wind turbine voltage source $\mathrm{V}_{\mathrm{in} 2}$ is applied to the primary winding of the couple inductor and current of the primary winding increases linearly. During this mode, Q1 and Q3 sustain the voltages of $\mathrm{V}_{\text {in1 }}$ and $\mathrm{V}_{\text {in3while }} \mathrm{D} 3$ sustain the secondary winding voltage of couple inductor, Vsec respectively.In the third mode, Q3 and Q4 are conducting and Q1 and Q2 are off. D1 and D2 are on while D3are blocked. The fuel-cell voltage source $\mathrm{V}_{\text {in } 3}$ is applied to the primary winding of the couple inductor and current of the primary winding increases linearly. During this mode, Q1 and Q2sustain the voltages of $V_{\text {in } 1}$

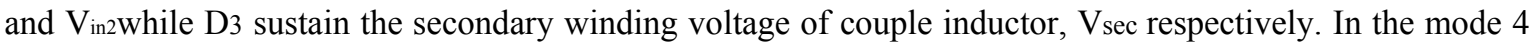
condition, Q1, Q2 and Q4 are conducting and Q3 are off. D1 and D2 are on while D3 are blocked. The photovoltaic voltage source $V_{\text {in1 }}$ and wind turbine voltage source $V_{\text {in2 }}$ is applied to the primary winding of the couple inductor and current of the primary winding increases linearly. During this mode, Q3sustain the voltage of $\mathrm{V}_{\text {in3while }} \mathrm{D} 3$ sustain the secondary winding voltage of couple inductor, $\mathrm{V}_{\text {sec }}$ respectively.

In the equivalent circuit for mode 5, Q2, Q3 and Q4 are conducting and Q1 are off. D1and D2 are on while D3 are blocked. The wind turbine voltage source $V_{\text {in2 }}$ and fuel cell voltage source $V_{\text {ins }}$ is applied to the primary winding of the couple inductor and current of the primary winding increases linearly. During this

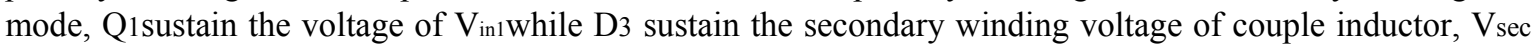
respectively.In the mode 6, Q1, Q3 and Q4 are conducting and Q2 are off. D1 and D2 are on while D3are blocked. The photovoltaic voltage source $V_{\text {in1 }}$ and fuel cell voltage source $V_{\text {in } 3}$ is applied to the primary winding of the couple inductor and current of the primary winding increases linearly. During this mode, Q2sustain the voltage of $\mathrm{V}_{\text {in2while }} \mathrm{D} 3$ sustain the secondary winding voltage of couple inductor, Vsec respectively.Mode 7shows all the power switches Q1, Q2, Q3 and Q4 are conducting, and D1and D2are conducting and D3 are all reversely blocked. The three input power sources $V_{\text {in1 }}, V_{\text {in2 }}$ and $V_{\text {in3 }}$ are connected in parallel, applying on the primary winding of the couple inductor. The current of the primary winding increases linearly. During this mode, only D3 sustain the secondary winding voltages of couple inductor, $\mathrm{V}_{\text {sec }}$ respectively. 
For the mode 8, Q1, Q2, Q3 and Q4 are all turned off, D1 and D2 are reversely blocked and D3 is on. The energy stored in the inductor of the couple inductor is released to the load through the secondary winding, and the current of the secondary winding decreases linearly. Q1, Q2, Q3, D1 and D2 sustain the voltages of $\mathrm{V}_{\text {in1, }} \mathrm{V}_{\text {in2 }}$ and $\mathrm{V}_{\text {in3, }}$, respectively. Lastly, Q1, Q2 and Q3 are all turned off and the energy stored in the couple inductor has been released completely and the load current is provided by C2. It's should be noted that this mode only exists under discontinuous current mode. From the above analysis, we can see that as long as when one of Q1, Q2 and Q3 is turned on, and Q4 must be turned on, and Q4 must be turned off at the same time when Q1, Q2 and Q3 are turned off. Practically, in Mode 1 through Mode 3, the input sources can power the load individually or separately, Mode 4 through Mode 6 the power deliver from two input sources simultaneously, and Mode 7 is combine all input sources to power the load simultaneously.

The converter is under continuous current mode, in which the power provided by photovoltaic

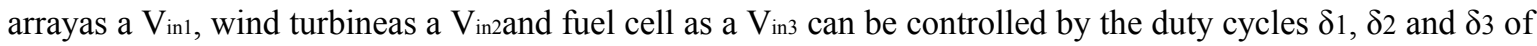
the power switches Q1, Q2 and Q3. In simulation, the assumption are that $\delta 1$ the duty cycle of Q1 is equal to $\delta 2$ the duty cycle ofQ2, and $\delta 2$ the duty cycle ofQ2 is equal to $\delta 3$ the duty cycle ofQ3.In modes 1 until 8 , the increase in the coupled inductor magnetic flux is governed by Eq. (9) to Eq. (16) respectively.

$$
\begin{aligned}
\Delta \emptyset_{+1_{1}} & =\frac{\mathrm{V}_{\mathrm{in} 1}}{\mathrm{~N}_{\mathrm{p}}} \delta_{1} \mathrm{~T}_{\mathrm{s}} \\
\Delta \emptyset_{+1_{2}} & =\frac{\mathrm{V}_{\mathrm{in} 2}}{\mathrm{~N}_{\mathrm{p}}} \delta_{2} \mathrm{~T}_{\mathrm{s}} \\
\Delta \emptyset_{+1_{3}} & =\frac{\mathrm{V}_{\mathrm{in} 3}}{\mathrm{~N}_{\mathrm{p}}} \delta_{3} \mathrm{~T}_{\mathrm{s}} \\
\Delta \emptyset_{+21} & =\frac{\left(\mathrm{V}_{\mathrm{in} 1} \delta_{1}+\mathrm{V}_{\mathrm{in} 2} \delta_{2}\right)}{2 \mathrm{~N}_{\mathrm{p}}} \mathrm{T}_{\mathrm{s}} \\
\Delta \emptyset_{+22} & =\frac{\left(\mathrm{V}_{\mathrm{in} 2} \delta_{2}+\mathrm{V}_{\mathrm{in} 3} \delta_{3}\right)}{2 \mathrm{~N}_{\mathrm{p}}} \mathrm{T}_{\mathrm{s}} \\
\Delta \emptyset_{+23} & =\frac{\left(\mathrm{V}_{\mathrm{in} 1} \delta_{1}+\mathrm{V}_{\mathrm{in} 3} \delta_{3}\right)}{2 \mathrm{~N}_{\mathrm{p}}} \mathrm{T}_{\mathrm{s}} \\
\Delta \emptyset_{+3}= & \frac{\left(\mathrm{V}_{\mathrm{in} 1} \delta_{1}+\mathrm{V}_{\mathrm{in} 2} \delta_{2}+\mathrm{V}_{\mathrm{in} 3} \delta_{3}\right)}{3 \mathrm{~N}_{\mathrm{p}}} \mathrm{T}_{\mathrm{s}}
\end{aligned}
$$

Where, Ts is a switching period.

The decrease in the coupled inductor magnetic flux is;

$$
\Delta \emptyset_{-}=\frac{\mathrm{V}_{\mathrm{o}}}{\mathrm{N}_{\mathrm{p}}}\left(1-\delta_{1}\right) \mathrm{T}_{\mathrm{s}}
$$

In a switching period, the coupled inductor magnetic flux is conservative, namely given by Eq. (17).

$$
\Delta \emptyset_{+1}+\Delta \emptyset_{+2}+\Delta \emptyset_{+3}=\Delta \emptyset_{-}
$$

From Eq. (9) to Eq. (17), the output voltage equation $V_{o}$ is derived as Eq. (18).

$$
\mathrm{V}_{\mathrm{o}}=\frac{1}{\mathrm{n}} \frac{\left(\mathrm{V}_{\mathrm{in} 1} \delta_{1}+\mathrm{V}_{\mathrm{in} 2} \delta_{2}+\mathrm{V}_{\mathrm{in} 3} \delta_{3}\right)}{3\left(1-\delta_{1}\right)}
$$

The input currents of three input sources can be obtained as stated in Eq. (19), Eq. (20) and Eq. (21) respectively. 


$$
\begin{aligned}
& \mathrm{I}_{\mathrm{in} 1}=\frac{\mathrm{I}_{\mathrm{o}} \delta_{1}}{\mathrm{n}\left(1-\delta_{1}\right)}+\frac{\left(\mathrm{V}_{\mathrm{in} 2} \delta_{2}+\mathrm{V}_{\mathrm{in} 3} \delta_{3}\right) / 2}{2 \mathrm{~L}_{\mathrm{p}}} \mathrm{T}_{\mathrm{s}} \\
& \mathrm{I}_{\mathrm{in} 2}=\frac{\mathrm{I}_{\mathrm{o}} \delta_{2}}{\mathrm{n}\left(1-\delta_{1}\right)}-\frac{\left(\mathrm{V}_{\mathrm{in} 1} \delta_{1}+\mathrm{V}_{\mathrm{in} 3} \delta_{3}\right) / 2}{2 \mathrm{~L}_{\mathrm{p}}} \mathrm{T}_{\mathrm{s}} \\
& \mathrm{I}_{\mathrm{in} 3}=\frac{\mathrm{I}_{\mathrm{o}} \delta_{3}}{\mathrm{n}\left(1-\delta_{1}\right)}-\frac{\left(\mathrm{V}_{\mathrm{in} 1} \delta_{1}+\mathrm{V}_{\mathrm{in} 2} \delta_{2}\right) / 2}{2 \mathrm{~L}_{\mathrm{p}}} \mathrm{T}_{\mathrm{s}}
\end{aligned}
$$

The average output current Io, Eq, (22) is found to be

$$
\mathrm{I}_{\mathrm{o}}=\frac{1}{2}\left(\mathrm{I}_{\mathrm{smin}}+\mathrm{I}_{\mathrm{smax}}\right)\left(1-\delta_{1}\right)
$$

Where, Ismax and Isminare the maximum and minimum value of the secondary winding current of the coupled inductor, respectively.

For the control strategies, the isolated three input flyback DC-DCconverter should achieve the following two functions: (i) output voltage regulation, and (ii) realize the power generation of the three input renewable energy sources. The regulating pulse width modulation is commonly used in the circuit to control the power switching device on and off by providing the pulse signal according to the duty cycle and switching frequency. Furthermore, the value of output is inadequate to conduct the gate terminal of the switch. So, the control circuit will function that can amplifies control signal which is voltage output of PWM to level required to drive these power switches. When the controller turns on $\left(t_{o n}\right)$ the mosfet, the couple inductor current, ILpwill increases linearly from zero to Ipk. During the turn-on period the energy is stored in the couple inductor. When the mosfet turns off $\left(\mathrm{t}_{\mathrm{off}}\right)$, the energy stored in couple inductor will deliver to the output of the power converter through the output rectifier.

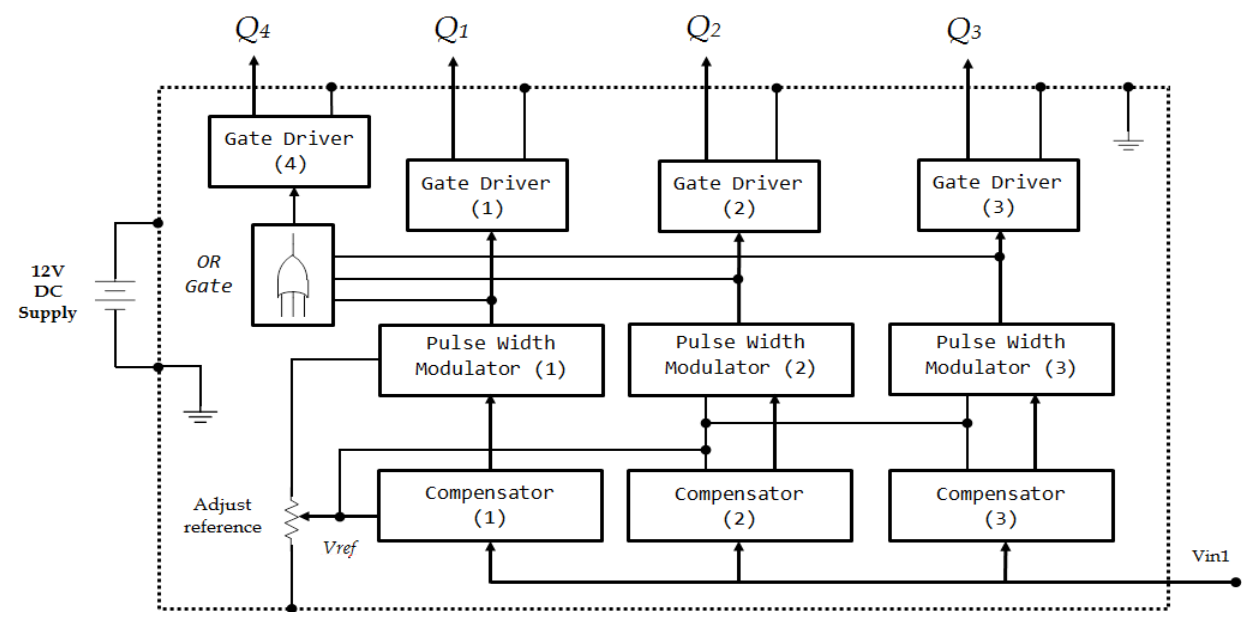

Figure 4. Block diagram of the control system for DC-DC converter

Figuew 4 shows the corresponding control system block diagram for proposed converter, including the $12 \mathrm{~V}$ dc supply, Compensator, Pulse Width Modulator (PWM) circuit, Gate Driver (GD) and OR gate. The PWM 1 through PWM 3 will generate desired gate signals for power switches Q1 through Q3 while OR gate will generate output signal for power switches Q4. The output signals of the Compensator 1, Compensator 2 and Compensator 3 are the drive signal of PWM Circuit 1, PWM Circuit 2 and PWM Circuit 3. The output signals of the PWM Circuit 1, PWM Circuit 2 and PWM Circuit 3 are the drive signal of GD Circuit 1, GD Circuit 2 and GD Circuit 3. The output signal of the GD Circuit 1, GD Circuit 2 and GD Circuit 3 are drive signal of switching devices Q1, Q2 and Q3 separately. The output signals from all PWM circuit is an input signals for the OR gate circuit. The output signal of OR gate is the driven at switching 
device Q4. The pulse signal of the Q1, Q2 and Q3 can be controlled by adjusted the duty ratio (d) and switching frequency (f) in the PWM circuits. The design implementation of the control circuit is realized by using the auxiliary analog circuits design. Implementation of control of power converter had been dominated with analogue control technique due to its simplicity and low cost.

\subsection{DC-AC Power Inverter and Controller}

For providing electric power to ac, the dc output of isolated three input flyback DC-DCconverter is regulated or inverted in a single phase full bridge dc-ac inverter. The inverter power is provided by the dc source and will inject a sinusoidal current into the ac mains. Usually a PWM controller is used to perform the tasks. This system is used to simplify the operation complexity and reduce the cost. The equivalent circuit of a typical single phase full bridge DC-AC inverter with the PWM controller for hybrid renewable energy generation system is shown in Figure 5. Transistors Q5 through Q10are used as power switching devices. In voltage source inverter, switches are represented by Darlington transistors. The output voltage (Vout) from inverter will be delivered to the PWM controller and sense by compensator as a feedback controlled. The output signal of compensator is an input signal for PWM circuit and can adjusted the voltage (Vref) as a reference for the PWM circuit. The output signal of the gate drive circuit is a drive signal to the switches Q5 through Q10 for producing sinusoidal AC current. In order to control the proposed DC-AC inverter properly, the central control unit need to sense the output voltage continuously. The design implementation of the control unit is realized by using the auxiliary analog control circuit.

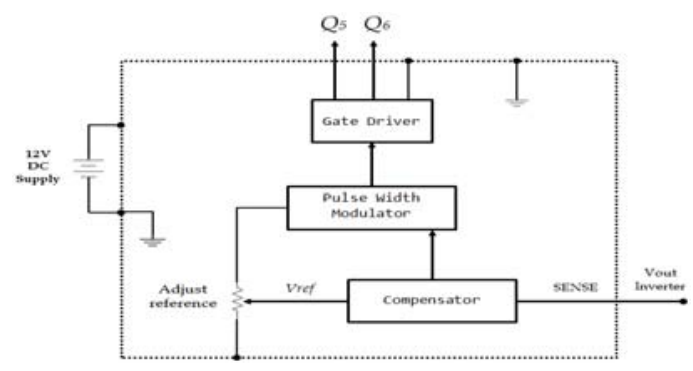

Figure 5. Block diagram of the control system for DC-AC inverter

\subsection{Performance Comparison}

The previous multi-input inverter consists of a buck/buck-boost fused multi-input DC-DC converter and a full-bridge DC-AC inverter [6], [7]. These power inverters are non-isolated circuit topology and regulated power by two input renewable energy sources to the load individually or simultaneously. These topologies are very complex configurations and will increase the number of power switches and components. To improve the power inverter design, the new multi-input inverter is proposed. It is consists of a multi-input flyback DC-DC converter and a single phase full-bridge DC-AC inverter. The proposed converter is an electrical isolation between the input and output, has a simple structure and suitable for hybrid renewable energy power system for input sources more than two. The parameters of the previous and proposed multiinput inverter are shown in Table 3.

Table 3. Comparison of input and output parameters

\begin{tabular}{|c|c|c|c|c|}
\hline \multicolumn{2}{|c|}{ Previous work [6] } & \multirow{2}{*}{$\begin{array}{l}\text { Previous work [7] } \\
250 \sim 450 \text { V DC }\end{array}$} & \multicolumn{2}{|c|}{ Proposed work } \\
\hline Solar voltage, $\mathrm{Vpv}$ & $230 \mathrm{~V} \mathrm{DC}$ & & Solar voltage, Vpv & $12 \sim 17.5 \mathrm{~V} \mathrm{DC}$ \\
\hline & & & Wind turbine voltage, Vwind & $12 \mathrm{~V} \mathrm{DC}$ \\
\hline Wind turbine voltage, $V$ wind & $80 \sim 200 \mathrm{VDC}$ & $80 \sim 200 \mathrm{VDC}$ & Fuel cell voltage, Vfc & $12 \mathrm{~V} \mathrm{DC}$ \\
\hline DC bus voltage, Vdc & $230 \mathrm{~V}$ DC & 230V DC & DC bus voltage, Vdc & $\pm 12 \mathrm{~V} \mathrm{DC}$ \\
\hline Output voltage, Vac & $110 \mathrm{~V} \mathrm{AC}, 60 \mathrm{~Hz}$ & $110 \mathrm{~V} \mathrm{AC}, 60 \mathrm{~Hz}$ & Output voltage, Vac & $240 \mathrm{~V} \mathrm{AC}, 50 \mathrm{~Hz}$ \\
\hline Output power, Pmax & $1 \mathrm{~kW}$ & $1 \mathrm{~kW}$ & Output power, Pmax & $250 \mathrm{~W}$ \\
\hline Converter topology & $\begin{array}{l}\text { Buck/buck-boost fused } \\
\text { converter }\end{array}$ & $\begin{array}{l}\text { Buck/buck-boost fused } \\
\text { converter }\end{array}$ & Converter topology & Flyback converter \\
\hline Input sources & 2 input, 1 battery & 2 input, 1 battery & Input sources & 3 input \\
\hline
\end{tabular}


Table 3 shows the concept of previous multi-input inverter. It is a complicated structure to combine two input power sources with the different high voltage levels in high voltage ranges and difficult to get regulated constant output voltage for the load from them. The proposed inverter accept up to three input sources by other competitors with the same voltage level in low voltage ranges to produce constant output voltage for the load. The ouput power is always in constant wether the input sources deliver power to the load individually or simultaneously.

\section{SIMULATION RESULTS}

The proposed system is implemented and simulated using NI Multisim 12.0 software. The output voltage and current are shown in Figure 6 to Figure 12. In order to verify the operation principle of the new multi-input inverter, a $250 \mathrm{~W}$ system was designed to supply a constant DC bus voltage of $12 \mathrm{~V}$ DC from a three input sources with the voltage range $12 \sim 17.5 \mathrm{~V} \mathrm{DC}$ and produce load voltage of $240 \mathrm{~V} \mathrm{AC}, 50 \mathrm{~Hz}$. The switching frequency of $100 \mathrm{kHz}$ is used for driving all the switching devices, Q1 Q4 of converter.

From the simulation results, Figure 6 shows the output voltage and current waveforms of the three input flyback DC-DC converter when the power is delivered to the DC-AC inverter by one input source individually (Vin1/Vin2/Vin3). Figure 7 shows the output voltage and current waveforms of the converter when the power is delivered to the inverter from two input sources simultaneously (Vin1+Vin2), (Vin2+Vin3) and $(\mathrm{Vin} 1+\mathrm{Vin} 3)$. The last condition, Figure 8 shows the output waveforms of converter when power delivered by all three input sources simultaneously $\left(V_{i n} 1+V_{i n} 2+V_{i n} 3\right)$. Figure 9 shows the sinusoidal output regulated voltage and current waveforms of the DC-AC inverter when the power from multi-input converter is delivered to the load by one input source individually (Vin1/Vin2/Vin3). Figure 10 shows the output regulated voltage and current waveforms of the inverter when the power is delivered to the load from two input sources simultaneously (Vin1+Vin2), (Vin2+Vin3) and (Vin1+Vin3). The last condition, Figure 11 shows the output regulated waveforms when power delivered by all three input sources simultaneously $(\mathrm{Vin} 1+\mathrm{V}$ in2 $+\mathrm{Vin} 3)$. Figure 12 shows the output voltage and output current in pure sinusoidal waveforms of single phase full-bridge DC-AC inverter.

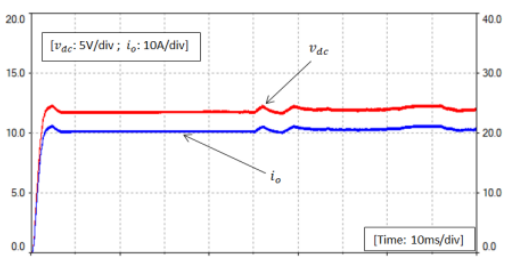

(a)

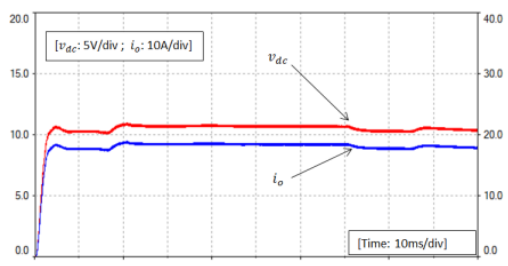

(b)

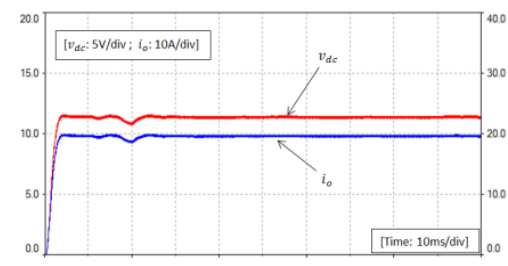

(c)

Figure 6. Output voltage and current of three input flyback DC-DC converter (a) Vin1 work individually, (b) Vin2 work individually and (c) Vin3 work individually

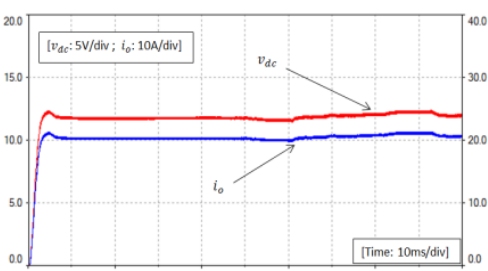

(a)

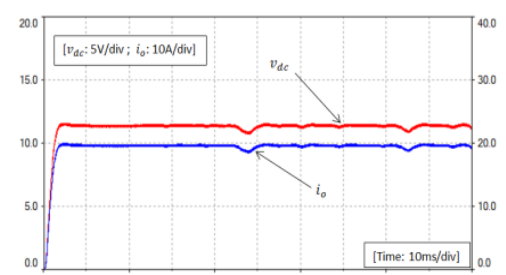

(b)

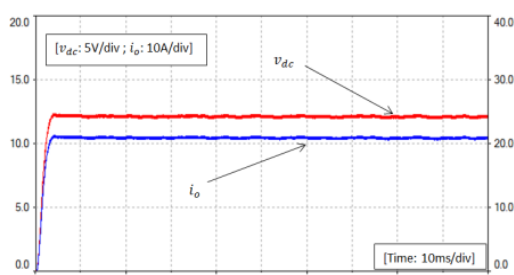

(c)

Figure 7. Output voltage and current of three input flyback DC-DC converter (a) Vin1 and Vin2 works simultaneously, (b) Vin2 and Vin3 works simultaneously and (c) Vin1 and Vin3 works simultaneously 


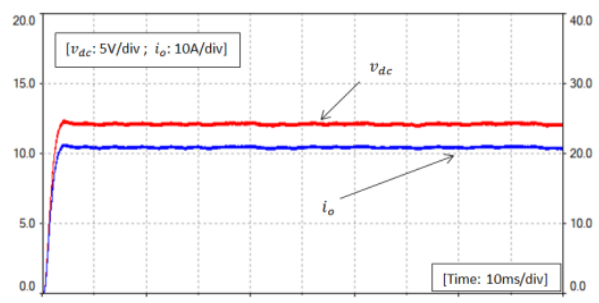

Figure 8. Output voltage and current of three input flyback DC-DC converter for three sources, Vin1, Vin2 and Vin3 works simultaneously

From the Figure 6 to Figure 8, we can see that voltage output and current output waveforms obtained in DC-DC mode operation of the proposed multi-input flyback DC-DC convertersare produced in same level of $12 \mathrm{~V} \mathrm{DC}$ and $\pm 21 \mathrm{~A}$. When $Q_{1}, Q_{2}, Q_{3}$ and $Q_{4}$ connected in parallel and opened condition, the voltage waveforms of them are in coincidence. That's mean the output voltage deliver to the DC-AC inverterare always constant either run in individually or simultaneously. The dc bus voltage of the converter is designed to be regulated on $V d c=12 \mathrm{~V}$ and power output with $P_{\max }=250 \mathrm{~W}$.

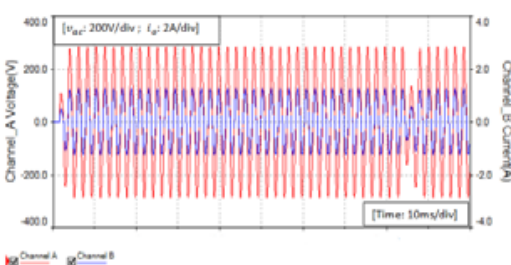

(a)

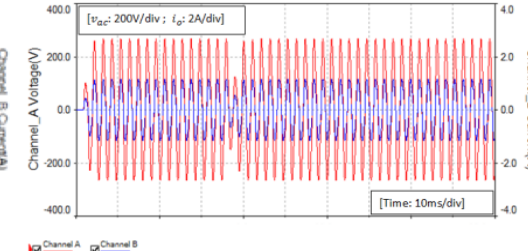

(b)

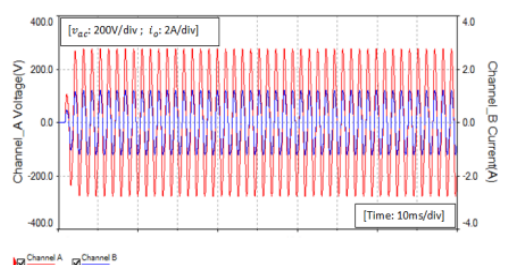

(c)

Figure 9. Output voltage and current of DC-AC inverter (a) Vin1 work individually, (b) Vin2 work individually and (c) Vin3 work individually

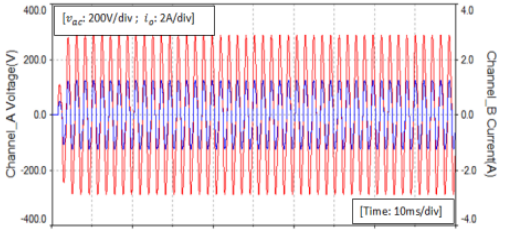

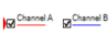

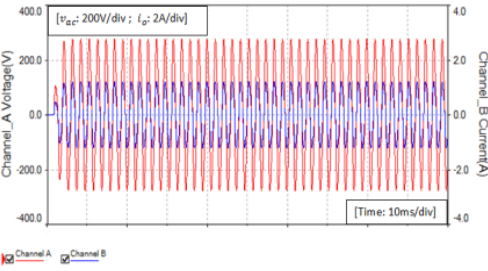

(b)

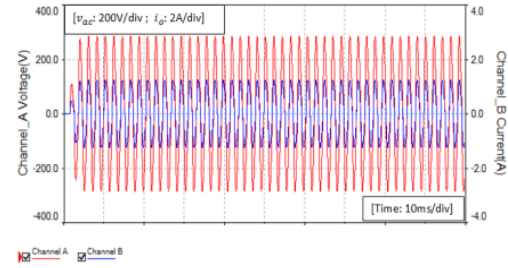

(c)

Figure 10. Output voltage and current of DC-AC inverter (a) Vin1 and Vin2 works simultaneously, (b) Vin2 and Vin3 works simultaneously and (c) Vin1 and Vin3 works simultaneously

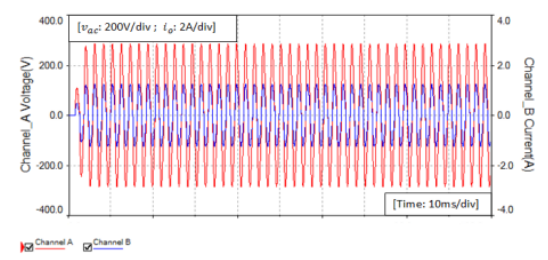

Figure 11. Output voltage and current of DC-AC inverter for three sources, Vin1, Vin2 and Vin3 works simultaneously 


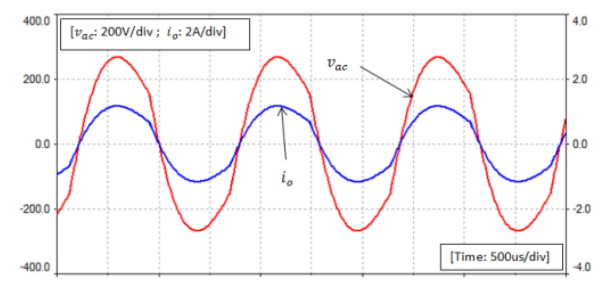

Figure 12. Pure sine wave inverter output voltage and current

Figure 9 to Figure 12 shows the output voltage and current waveforms obtained in DC-AC mode operation of the proposed single phase full-bridge dc-ac inverter topology. The output power of the inverter is designed to be regulated on $\mathrm{Vac}=240 \mathrm{~V}$ and power output with Pmax $=250 \mathrm{~W}$. From the results it is clear that perfect constant sinusoidal ouput when power deliver from multi-input flyback converter in individually or simultaneously. The results are obtained with using a harmonic filter.

\section{CONCLUSION}

A multi-input inverter design consists of a three input flyback DC-DC converter and a full-bridge DC-AC inverter is explained. Lesser number of power switches and active components are used in this topology. This multi-input dc-ac inverter is capable of being operated in five conditions and the power from the three input sources can be delivered to ac load individually or simultaneously. Simulation results under different operating conditions are shown here to verify the performance of the proposed multi-input inverter system with the desired features. The control circuit is implemented by using an auxiliary analog circuit design to accomplish the desired control functions and circuit protection. From the simulation results, it is confirmed that with a well-designed system including a proper inverter and controller, and selecting of an efficient and proven algorithm is simple and can be easily constructed to achieve an acceptable efficiency to produce a constant output voltage from the different energy sources. In comparison with the previous topologies of hybridizing, three input sources with the proposed inverter can economize the number of power components, simple structure, high extendibility and flexibility, making it well suited for hybrid renewable energy application for three input power sources with same voltage input level.

A successful outcome, through design and development of efficient hybrid energy integration scheme would improve performance and usage of renewable generation, consequently improving electricity supply efficiency and availability, thereby promoting economic usage of renewable generation, resulting in reduced greenhouse gas emissions and consequently contributing to the achievement of global climate change. The future enhancement of this work is to realize a model or prototype of the multi-input inverter for hybrid renewable energy power system.

\section{ACKNOWLEDGEMENTS}

The authors wish to thank the Universiti Teknologi PETRONAS (UTP) and MyRA for providing financial support for the publication of this work.

\section{REFERENCES}

[1] Darus ZM, Atikah N, Nurhidayah S, Azhar M, Nizam K, Karim OA. The development of hybrid integrated renewable energy system (wind and solar) for sustainable living at Perhentian Island, Malaysia. European Journal of Social Sciences. 2009; 9(4): 557-563.

[2] Dharani M, Usha P. A novel topology for controlling a fout port dc-dc boost converter for a hybrid PV/PV/battery power system. TELKOMNIKA Indonesian Journal of Electrical Engineering. 2015; 14(3): 446-454.

[3] Sathya S, Vinoth kumar B. Modeling and control of hybrid systems-solar/wind/battery using three inputs dc-dc boost converter. International Journal of Advanced Research in Electrical, Electronics and Instrumentation Engineering. 2014; 3(2): 7320-7326.

[4] Kamalakkannan S, Tina Devi T. Simulation of multi input dc-dc boost converter for hybrid PV/FC/super capacitor power systems. International Journal of Power Control and Computation. 2013; 5(2): 47-52.

[5] Ramya S, Manokaran T. Analysis and design of multi-input dc-dc converter for integrated wind PV cell renewable energy generated system. International Journal of Recent Technology and Engineering. 2012; 1(5): 14-19. 
[6] Sivakumar N, Sumathi A. Control of hybrid system using multi-input inverter and maximum power point tracking. International Journal of Engineering Research and Applications. 2013; 3(4): 77-81.

[7] Chen YM, Liu YC, Hung SC, Cheng CS. Multi-input inverter for grid-connected hybrid PV/wind power system. IEEE Transactions on Power Electronics. 2007; 22(3): 1070-1077.

[8] Salazar L, Urra J. A novel two input single switch dc-dc converter for hybrid electricity generators.Canadian Journal on Electrical and Electronics Engineering. 2011; 2(11): 536-541.

[9] Chiang SJ, Chang KT, Yen CY. Residential photovoltaic energy storage system. IEEE Trans. Ind. Electron. 1998; 45(3): 385-394.

[10] Snyman DB, Enslin JHR. Combined low-cost, high-efficient inverter, peak power tracker and regulator for PV applications. IEEE Tran. Power Electron. 1991; 6(1): 73-82.

[11] Abdulkadir M, Samosir AS, Yatim AHM. Modeling and simulation based approach of photovoltaic system in simulink model.ARPN Journal of Engineering and Applied Sciences. 2012; 7(5): 616-623.

[12] Hohm DP, Ropp ME. Comparative study of maximum power point tracking algorithms. Progress in Photovoltaics: Research and Applications. Brookings, USA. 2003; 11: 47-62.

[13] Mahalakshmi M, Latha S. Modeling, simulation and sizing of photovoltaic /wind/fuel cell hybrid generation system.International Journal of Engineering Science and Technology. 2012; 4(5): 2356-2365.

[14] Amei K, Takayasu Y, Ohji T, Sakui M. A maximum power control of wind generator system using a permanent magnet synchronous generator and a boost chopper circuit. Power Conversion Conference.Osaka, Japan. 2002; 3: 1447-1452.

[15] Cardenas R, Pena R, Asher G, Cilia J. Sensorless control of induction machines for wind energy applications. Power Electronics Specialists Conference. 2002; 1: 265-270.

[16] Palma L, Enjeti PN. A modular fuel cell, modular dc-dc converter concept for high performance and enhanced reliability. IEEE Trans. Power Electronics. 2009; 24(6): 1437-1443.

[17] Yang Y, He X, Shao R, Xu S, Chang L. Multi-input single-phase grid-connected inverter for hybrid PV/wind power system. International Journal of Renewable and Sustainable Energy. 2014; 3(2): 35-42.

[18] Riku Pasonen. Model of bi-directional flyback converter for hybrid ac/dc distribution system. International Journal of Power Electronics and Drive Systems. 2013; 3(4): 444-449.

[19] Daison Stallon S, Vinoth Kumar K, Suresh Kumar S. High efficient module of boost converter in PV module. International Journal of Electrical and Computer Engineering. 2012; 2(6): 758-765.

\section{BIOGRAPHIES OF AUTHORS}

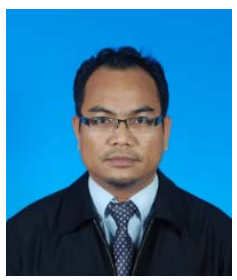

Mohd Azman Rosli was born in Kuala Lumpur, Malaysia, on October 3, 1978. He received the B.Tech. and M.E. degrees from Malaysia University of Technology, Skudai, Johor, Malaysia, in 2001 and 2010, respectively, both in electrical engineering. In 2001, he joined the Goodyear (M) Berhad, Shah Alam, Selangor, Malaysia, in an Engineering Department. He has 9 years of teaching experience as lecturer in electrical technology, Community College, Sabak Bernam, Selangor, Malaysia. Currently he is doing research in the field of power converter for renewable energy hybrid power system.

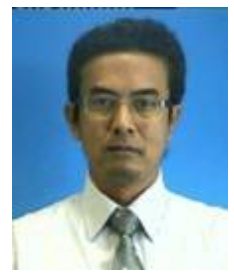

Nor Zaihar Yahaya was born in Lumut, Malaysia. He went to the University of Missouri-Kansas City, USA to study electronics and graduated with BSc in Electrical Engineering in 1996. After that he served 5 years in the industry in Malaysia. In 2002, he was awarded the MSc in Microelectronics from the University of Newcastle Upon Tyne, UK and later in 2011, he was granted with $\mathrm{PhD}$ in Electrical Engineering from Universiti Teknologi PETRONAS, Malaysia. Since then, he has published more than 40 papers in proceedings, cited journals and book chapter as well as secured several national and internal grants. His main teaching and research areas are the study of Power Electronics, Renewable Energy, Li-Fi technology, high powered PCB and device lithography.

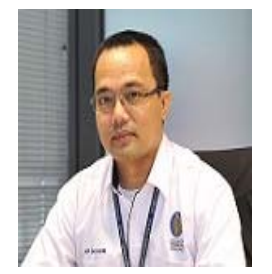

Zuhairi Baharudin was born in Malaysia. He went to the Universiti Teknologi MARA, Malaysia to study electrical and graduated with BEng (Honours) in Electrical Engineering. After He was awarded the MEng and PhD in Electrical Power from the University of South, Autralia. Since then, he has published more papers in proceedings, cited journals and book chapter as well as secured several national and internal grants. His main specializations are the study of Forecasting, Power System Planning, Time Series Applicationand Artificial Intelligence. Currently he is doing research in the field of Time Series Application in Load Forecasting. 